https://doi.org/10.31470/2706-7904-2020-15-146-148

\title{
ОСОБЛИВОСТІ РОЗВИТКУ ОПЕРАЦІЙ ВИНИКНЕННЯ МОТИВІВ РОЗПОВІДІ В ДІТЕЙ ДОШКІЛЬНОГО ВІКУ
}

\section{Features of the Development of Operations the Emergence of Narrative Motives in Preschool Children}

\author{
Yuliia Krolivets \\ Ph.D. in Psychology, Lecturer \\ Hryhorii Skovoroda State University in Pereiaslav (Ukraine) \\ yuliadiadiusha@ukr.net \\ https://orcid.org/0000-0003-2476-5772
}

\begin{abstract}
Absrtact
The article reveals the features of the development of operations for the emergence of narrative motives in preschool children. The motivational-intentional criterion and corresponding indicators are highlighted. It was found that the motives for creating a story in preschool children are not formed: unstable, non-independent, caused either by game situations or educational tasks.
\end{abstract}

Key words: story, motives, criterion, operations, preschool children.

\section{Вступ \\ Introduction}

Мета дослідження - виявити особливості розвитку операцій виникнення мотивів розповіді в дітей дошкільного віку.

У процесі вивчення операцій виникнення мотивів розповіді в дітей дошкільного віку виокремлено мотиваційно-інтенційний критерій та відповідні йому показники: сталість $i$ самостійність мотивів, пізнавальна спрямованість мовленнєвих мотивів, соціальна спрямованість мотивів. Мотиваційно-інтенційний критерій виділено з урахуванням того, що мотивація, згідно з Л.С. Виготським, $\epsilon$ першою фазою утворення мовлення. Вчений зазначав, що думка народжується 3 мотивуючої сфери свідомості, охоплюючи прагнення i потреби, інтереси i спонукання, афекти й емоції (Выготский, 2011). Тобто, мотивація є найглибшим початковим моментом формування висловлювання, пов'язаного з бажанням більш 
чітко сформулювати свою думку (Калмикова, 2011). Згідно 3 означеними показниками досліджувалися такі операції мотивів розповіді: виникнення мотивів, самостійного управління своєю мотивацією, вияву незмінного, інтенсивного інтересу до процесу розповідання та вербального контактування дітей з учасниками комунікативного процесу.

\section{Методи та методики дослідження} Methods and Techniques of the Research

У процесі проведення психодіагностичного дослідження використовувалися методи: спостереження, бесіда, опитування дітей - фіксація їхніх висловлювань на диктофоні, вивчення розповідних продуктів діяльності дошкільників.

\section{Результати \\ Results}

При вивченні в дітей операцій виникнення мотивів, самостійного управління своєю мотиваџією, вияву інтенсивного інтересу до процесу розповідання виявлено, що в процесі створення розповіді діти відволікаються, відходять від теми, згадуючи окремі події з власного життя. У 4.04\% дітей до початку продукування наративу $є$ інтерес, однак в процесі розповідання цей інтерес згасає. 83.94\% дітей середнього та $85.02 \%$ старшого дошкільного віку із 247 опитаних подобається розповідати, проте 74.89\% дітей обох груп вибрали б у ситуації вибору виконання інших видів діяльності, наприклад, гратися, малювати, бігати тощо. 21.50\% дітей середніх та 40.06\% дітей старших груп ЗДО погодились скласти історію не тому, що в них виникла потреба висловитись, а тому, що запропонував їм це вихователь. 21.42\% дітей середнього та 39.67\% дітей старшого дошкільного віку виявляють пізнавальну спрямованість у власній мовленнєвій поведінці. Вони намагаються виконати мовленнєві завдання правильно, ставити запитання досліднику, якщо в них виникають труднощі в реалізації експериментальних завдань. У процесі вивчення операцій вербального контактування дітей з учасниками комунікативного процесу визначено, що діти помиляються у визначенні схожих емоційних станів людини, наприклад замість емоції радості вони вказують на емоцію суму, замість емоції здивування - емоцію злості (11.11\% і 6.61\% дошкільників). Допускають незначні помилки, коли замість емоції радості обирають емоцію сміху (18.25\% і 14.04\%), або на емоцію суму вказують емоцію злості, розчарування (15.87\% і 12.39\%) та ін. 


\section{Висновки}

\section{Conclusions}

На основі отриманих даних можемо зробити висновок, що мотиви створення розповіді в дітей дошкільного віку нестійкі, несамостійні, викликані або ігровими ситуаціями, або навчальними завданнями. Мовлення дітей полімотивоване, потреби в комунікації не пов'язуються з мовленнєвим самовираженням у розповіді.

\section{Література \\ References}

Выготский, Л.С. (2011). Мышление и речь. Москва: АСТ: Астрель.

Калмикова, Л.О. (2011). Психологія розвитку мовленнєвої діяльності дітей дошкільного віку. Дис. д-ра психол. наук. Київ. 